\title{
Besinning oor die diakonale dienswerk na aanleiding van Handelinge 6:1-7
}

\author{
G. Breed \& D.G. Breed \\ Skool vir Kerkwetenskappe \\ Potchefstroomkampus \\ Noordwes-Universiteit \\ POTCHEFSTROOM \\ E-pos: gert.breed@nwu.ac.za \\ dbreed@telkomsa.net
}

\begin{abstract}
Reflection on diaconal service in relation to Acts 6:1-7

Acts 6 is traditionally considered as the description of the origin of the special service of deaconship. The essence and duty of diaconal service is inferred from Acts 6:1-7; it is the service responsible for the care of the poor and promotion of mutual support and love in the church. This article re-examines Acts 6. It investigates whether this text truly describes diaconal service and what it conveys about the content and essence of the seven's service. This study shows that Acts 6 does not describe the institution of a special service (office) and that the content and essence of the special diaconal service cannot be derived from this text. Acts 6:1-7 is a description of the dynamic work of the Holy Spirit within the church, related to the difficulties that arise with service (Siakovía) due to rapid growth.
\end{abstract}

\section{Opsomming}

Besinning oor die diakonale dienswerk na aanleiding van Handelinge 6:1-7

Handelinge 6 word tradisioneel beskou as die beskrywing van die ontstaan van die besondere diens van die diaken. Uit Handelinge 6:1-7 word gewoonlik die wese en die taak van diakonale dienswerk afgelei, naamlik dat dit 'n diens is wat die versorging van die armes in die gemeente behartig en die onderlinge meelewing en liefde moet bevorder. In hierdie artikel word Handelinge 6 opnuut ondersoek. Daar word ondersoek ingestel of die gedeelte inderdaad die ontstaan van die diakonale diens beskryf en wat dit sê oor die inhoud en wese van die sewe se dienswerk. Uit die ondersoek word dit duidelik 
dat Handelinge 6 nie die instelling van 'n nuwe besondere diens (amp) beskryf nie en dat die inhoud en wese van die besondere diakonale diens nie hieruit afgelei kan word nie. Handelinge 6:1-7 beskryf eerder die dinamiese werking van die Heilige Gees binne 'n gemeente waarin daar weens die vinnige groei probleme ontstaan ten opsigte van die bedieningswerk (Siakovía).

\section{Inleiding}

Handelinge 6 word tradisioneel beskou as die beskrywing van die ontstaan van die besondere diens van die diaken. 1 Uit Handelinge 6 word ook die wese en die taak van diakonale dienswerk afgelei, naamlik dat dit 'n diens is wat die versorging van die armes in die gemeente behartig en die onderlinge meelewing en liefde moet bevorder. In hierdie artikel word Handelinge 6 opnuut ondersoek. Daar word ondersoek ingestel of die gedeelte inderdaad die ontstaan van die besondere diens van die diaken beskryf en wat dit sê oor die inhoud en wese van die sewe se dienswerk. Ander Skrifgedeeltes word net ondersoek in sover dit tot die verstaan van Handelinge 6 kan bydra.

Eerstens word aandag gegee aan die struktuur van die boek Handelinge en die plek wat Handelinge 6:1-7 binne hierdie struktuur inneem. Hierna word ondersoek ingestel of die mans wat volgens Handelinge 6 gekies is, sewe diakens was. Om dit te bepaal, word eerstens die probleem wat in die gemeente ontstaan het, ondersoek. Vervolgens word gevra wat die taak was waarop die apostels wou konsentreer. Wanneer die verband van Handelinge 6:1-7 ten opsigte van die res van die Bybelboek bepaal is, die probleem van die weduwees ontleed is en vasgestel is wat die apostels se taak was, kan bepaal word wat die inhoud en wese van die sewe mans se opdrag was.

\section{Die plek van Handelinge 6:1-7 in die boek Handelinge}

\section{1 'n Geheelbeeld van die boek Handelinge}

Die samestelling en logiese ontwikkeling in die boek Handelinge kan op verskeie wyses beskryf word. Petrus en Paulus se werk kan as

$1 \quad$ In hierdie artikel word uitgegaan van die onderskeid wat Breed et al. (2008:1920) tref ten opsigte van die besondere en algemene dienste in die kerk. 
die merkers gesien word om die boek in twee dele te verdeel. Die geografiese uitbreiding van die evangelie wat in Handelinge 1:8 beskryf word, kan as struktuurmerkers gebruik word om die boek in drie hoofdele op te deel (Wallace,1998:12; Barclay, 2003:6). Talbert (2005:v) gebruik Jesus se opdrag in Handelinge 1:8 as kriterium om die boek in twee hoofdele te verdeel, waarvan die laaste hoofdeel weer in twee onderafdelings verdeel kan word.

Talbert (2005) se indeling word in hierdie artikel gebruik. Dit kan soos volg uiteengesit word:

a. Ontvangs en voorbereiding vir die opdrag (Hand. 1:1-24)

b. Uitvoering van die opdrag

- Eerste fase (Hand. 2:1-12:25)

- Geboorte en uitbreiding van die kerk in Jerusalem (Hand. 2:18:4)

- Uitbreiding na Judea en Samaria (Hand. 8:5-9:31)

- Uitbreiding na Antiogië (Hand. 9:32-12:25)

- Tweede fase (Hand. 13:1-28:31): Paulus se sendingreise en die uitbreiding van die kerk na Klein-Asië.

Dit is duidelik dat Handelinge 6:1-7 volgens hierdie indeling deel is van die tweede hoofdeel (Hand. 2:1-12:25) van Handelinge. In die tweede hoofdeel is dit deel van die eerste onderafdeling wat spesifiek handel oor die geboorte en uitbreiding van die kerk in Jerusalem (Hand. 8:5-9:31).

\subsection{Handelinge 6:1-7 binne die tweede hoofdeel van Handelinge (2:1-12:25)}

Talbert (2005:57) toon aan dat die kerk se getuienis in Handelinge 1-8 in 'n siklus met drie bene beskryf word. Handelinge 6:1-8:4 is die derde been van hierdie siklus. Die ander twee bene word gevind in Handelinge 1:12-4:23 en Handelinge 4:24-5:42.

Dieselfde struktuur word in al drie hierdie dele gebruik om die geskiedenis weer te gee (Talbert, 2005:34, 35). In al drie dele:

- word verhaal hoe die getuies van die evangelie voor die Joodse Raad gebring word (Hand. 4:3; 5:17, 18; 6:12); 
- verdedig die getuies hulle saak voor die Raad (Hand. 4:5-12; 5:27-32; 7:1-54);

- word die reaksie van die Raad weergegee:

- hulle bespreek die saak (Hand. 4:16-17) en laat die dissipels vry met 'n waarskuwing (Hand. 4:21);

- hulle weerhou hulleself daarvan om die dissipels dood te maak (Hand. 5:33-39) en laat die dissipels vry nadat hulle geslaan is (Hand. 5:40);

- hulle stenig Stefanus (Hand. 7:54, 57, 58).

- word die apostels en die gemeente versterk in hulle geloof en die verspreiding van die evangelie word bevorder (Hand. 4:29-31; $5: 11-14 ; 5: 41,42 ; 6: 7 ; 8: 4)$.

Die struktuur wat Talbert (2005) voorstel, kan soos volg uitgebrei word:

\section{A1 Die kerk groei ondanks en as gevolg van 'n aanslag van buite (Hand. 3:1-4:31)}

- God openbaar Hom deur 'n wonderwerk wat Petrus doen (Hand. 3:1-11).

- Dit skep die geleentheid om die evangelie te verkondig (Hand. 3:12-26).

- Die verkondiging wek die argwaan van die geestelike voorgangers en lei tot Petrus en Johannes se gevangeneming (Hand. $4: 1-3)$.

- Baie mense kom tot bekering (Hand. 4:4).

- Hulle word deur die Joodse Raad ondervra (Hand. 4:5-7), wat weer die geleentheid skep vir getuienis (Hand. 4:8-14).

- Die Joodse leiers is nie in staat om Petrus en die ander apostels gevange te hou nie en hulle word vrygelaat (Hand. 4:15-22).

- Die gelowiges loof God omdat die vyande van God magteloos is om sy plan te keer (Hand. 4:23-28).

- Die apostels se vrymoedigheid neem toe en die kerk groei (Hand. 4:29-31). 
B1 Die kerk groei ondanks en as gevolg van 'n aanslag van binne (Hand. 4:32-5:14)

- God openbaar Hom in die eenheid en onderlinge liefde binne die gemeente (Hand. 4:32-37).

- Ananias en Safira se oneerlikheid skep 'n bedreiging vir die groei van die kerk (Hand. 5:1, 2, 7-9).

- Die Here openbaar hulle leuens aan Petrus en Ananias en Safira sterf omdat hulle vir die Gees gelieg het (Hand. 5:3-5, 9, 10).

- Daar kom ontsag vir God by die mense (Hand. 5:11, 13).

- Die apostels doen baie wonders (Hand. 5:12) en die kerk groei (Hand. 5:14).

A2 Die kerk groei ondanks en as gevolg van 'n aanslag van buite (Hand. 5:15-42)

- Die apostels doen baie wonders (Hand. 5:15, 16).

- Dit wek die jaloesie van die hoëpriester en die Sadduseërs (Hand. 5:17).

- Die apostels word in die tronk gegooi (Hand. 5:18).

- 'n Engel bevry die apostels (Hand. 5:19).

- Hulle kry opdrag om die Woord te gaan verkondig (Hand. 5:20) en doen dit ook (Hand. 5:21a).

- Die Joodse Raad is magteloos om hulle gevange te hou en waarsku hulle net (Hand. 5:21-28; 33-40).

- Hierdie gebeure skep die geleentheid vir getuienis (Hand. 5:29).

- Die apostels gaan voort met die verkondiging van die Woord en die kerk groei (Hand. 5:41, 42).

B2 Die kerk groei ondanks en as gevolg van 'n aanslag van binne (Hand. 6:1-7)

- Die groei van die kerk in Jerusalem en die gepaardgaande omvang van die bediening veroorsaak dat die Griekssprekende weduwees oor die hoof gesien word in die daaglikse bediening (Hand. 6:1). 
- Dit laat verdeeldheid tussen Grieks- en Hebreeussprekende Jode ontstaan (Hand. 6:2).

- Die twaalf apostels roep die menigte bymekaar (Hand. 6:2).

- Die probleem word opgelos deur die verkiesing van sewe mans wat aangestel word om die probleem te hanteer (Hand. 6:3-6).

- Die Woord van die Here versprei (Hand. 6:7).

- Die gemeente groei (Hand. 6:7).

C Die kerk groei ondanks 'n skynbaar suksesvolle aanslag van buite (Hand. 6:8-8:4)

- Stefanus verkondig die Woord, maar word gestenig en sterf (Hand. 6:8-7:60).

- Hy sterf egter as oorwinnaar en hy bid vir sy moordenaars (Hand. 7:58-60; Talbert, 2005:60).

- Hy sien Jesus Christus aan God se regterhand staan (Hand. 7:55). ${ }^{2}$

- Die vervolging wat ná Stefanus se dood ontstaan, lei daartoe dat die evangelie nog verder versprei (Hand. 8:4).

Uit bostaande is dit duidelik dat daar 'n groeiende woede onder die evangelie se vyande is. Dit groei van 'n waarskuwing (Hand. 4:21) na geselhoue (Hand. 5:40) tot steniging (Hand. 7:54-58; Talbert, 2005:57). Die evangelie versprei ondanks hierdie verwoede aanslag.

In die gebeure is daar ' $n$ besondere ontwikkeling ten opsigte van God se betrokkenheid. In die eerste drie dele (A1, B1, A2) gryp God wonderbaarlik in. In die vierde deel (B2) lei die Gees van God die apostels en die gemeente om 'n oplossing uit te werk sonder 'n wonderwerk (vgl. Talbert, 2005:60). In die vyfde deel (C) is God nie sigbaar betrokke nie en laat Hy toe dat sy dienskneg sterf. Dit lyk asof Hy toelaat dat die kerk vernietig word. Dit is egter duidelik dat Jesus Christus die skynbare nederlaag as die saad gebruik wat die evangelie verder laat versprei (Hand. 8:1-4).

2 Dat Jesus staan kan verskeie dinge beteken (vgl. Talbert, 2005:64, 65); dit beeld minstens Jesus, die Oorwinnaar, se betrokkenheid by Stefanus en dit wat met hom gebeur uit. 
Uit die voorafgaande is die volgende duidelik:

- Lukas beskryf in Handelinge die geskiedenis van die ontstaan en groei van die kerk en hy doen dit gestruktureerd.

- Die volgende deurlopende temas kom in hierdie deel na vore:

- Die aanslag van binne en buite om die groei van die kerk te stuit

- Die groei van die kerk ondanks en selfs as gevolg van die aanslag

- God wat wonderbaarlik sorg

- Jesus wat sy belofte dat die evangelie gaan versprei, nakom en so uit die hemel regeer

- Die mens wat verantwoordelikheid moet aanvaar en in die krag en wysheid van die Gees oplossings moet vind

- Die Woord van God wat 'n sentrale plek in die groei van die kerk beklee

- Lukas beklemtoon dat daar 'n groeiende woede onder die evangelie se vyande is.

- Die geskiedenis wat opgeteken is, toon 'n besondere ontwikkeling ten opsigte van die wyse waarop God se betrokkenheid na vore kom.

- Handelinge 6:1-7 beskryf 'n tweede voorbeeld van die aanslag wat die kerk van binne beleef het en hoe die aanslag deur die wysheid van die Gees afgeweer is.

- Handelinge 6:1-7 is deel van 'n goed-gestruktureerde, groter geheel waarin die geskiedenis van die kerk beskryf word. Hierdie struktuur moet in ag geneem word in die verklaring van hierdie verse.

\section{Handelinge 6 en die besondere diakonale diens (diakenamp)}

Om te bepaal of Handelinge 6 oor die instelling van 'n nuwe besondere diens handel en wat dan die aard en inhoud van so 'n besondere diens sal wees, word eerstens 'n oorsig oor die gebeure gegee. Daarna word gevra wat die probleem in die gemeente volgens Handelinge 6 was en wat presies die apostels se taak was. 


\subsection{Samevatting van die gebeure wat in Handelinge 6:1-7 beskryf word}

Handelinge 6:1 verhaal dat daar in daardie spesifieke tydperk ('Ev $\delta \grave{\varepsilon}$

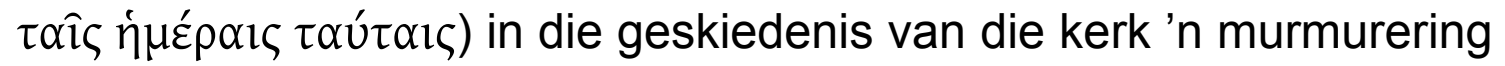

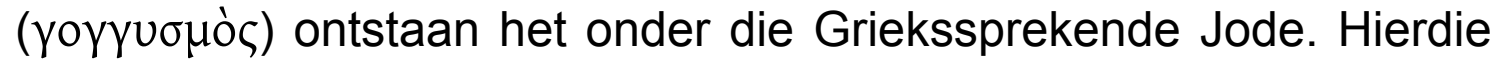
ongelukkigheid was gerig teen die Hebreeussprekendes. Die rede vir die ongelukkigheid was dat die weduwees van die Griekssprekendes op die een of ander manier in die daaglikse bediening

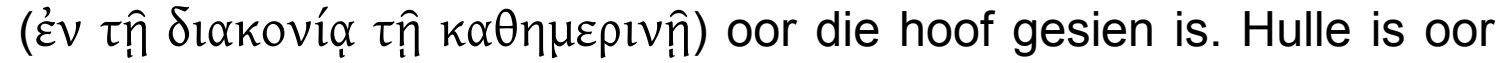
die hoof gesien weens die vinnige groei van die gemeente $(\pi \lambda \eta \theta u v o ́ v \tau \omega v \tau \hat{\omega} v \mu \alpha \theta \eta \tau \hat{\omega} v)$ en die gepaardgaande groeiende omvang van die werk.

Dit is nie duidelik of die apostels voorheen die bediening van die tafels behartig het en of die gelowiges dit spontaan onderling behartig het en die groter getalle ' $n$ meer gestruktureerde bediening genoop het nie. Die apostels het egter besef dat hulle nie alles alleen kan doen nie en hulp moes kry. Hierna moes hulle duidelikheid kry oor wat hulle primêre taak is en watter deel van hulle verpligtings hulle aan iemand anders kan oorlaat. Die apostels deel die bediening in twee dele. Aan die een kant die gebede en

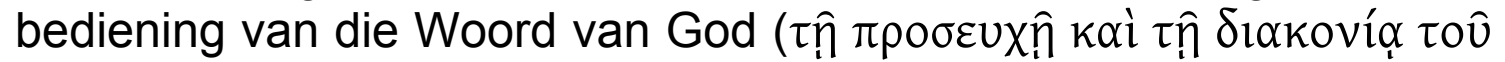

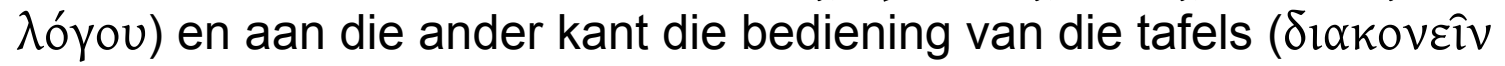

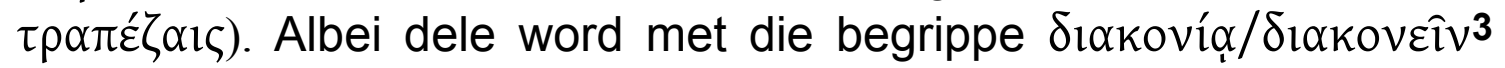
beskryf.

Die apostels het die hele gemeente saamgeroep, aan hulle die probleem geskets en voorgestel dat hulle sewe mans uit hulle geledere

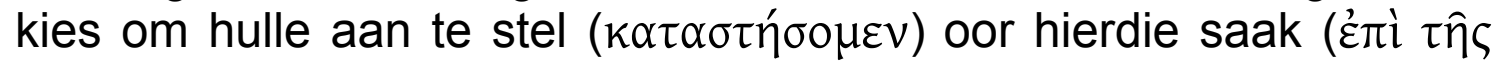

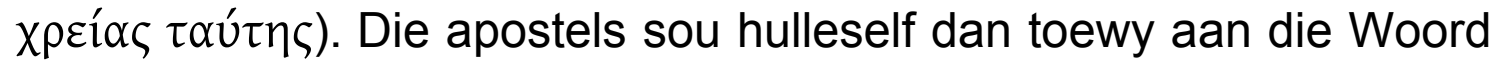
en die gebede. Hierdie voorstel het byval by die gemeente gevind en hulle het sewe mans gekies en hulle voor die apostels gebring

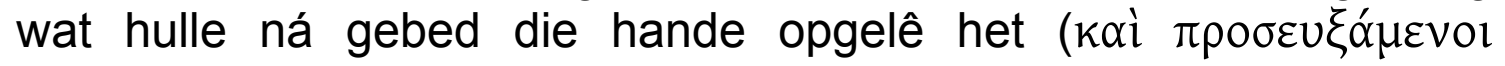

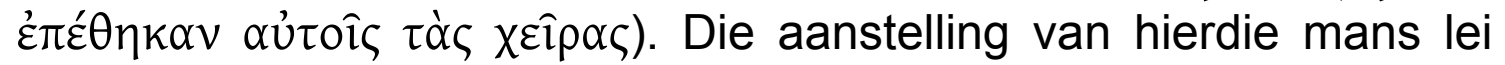
daartoe dat die hindernis vir die verspreiding van die Woord uit die weg geruim is.

3 Wanneer verder in hierdie artikel na die diakon-woordgroep verwys word, word

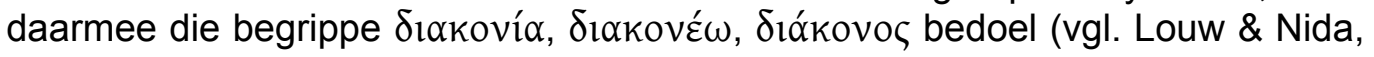
1989, 2:59). 


\subsection{Die klagte van die weduwees}

Die nood van die weduwees was dat hulle oor die hoof gesien is in

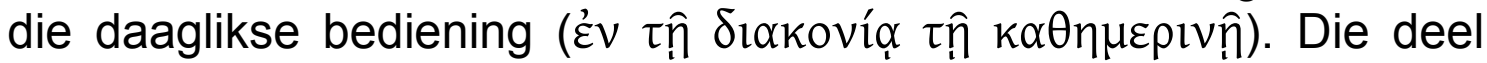
van die werk wat die apostels sou afstaan, word beskryf as die

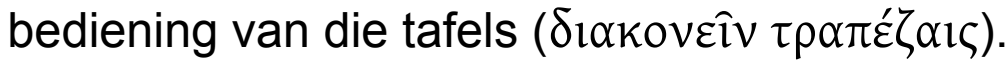

\subsubsection{Die weduwees en die $\delta 1 \alpha k o v i ́ \alpha$}

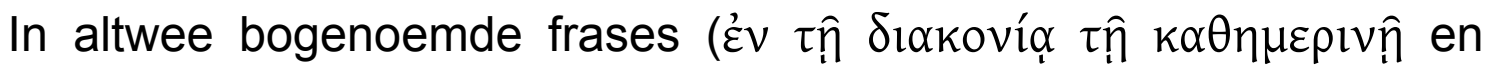

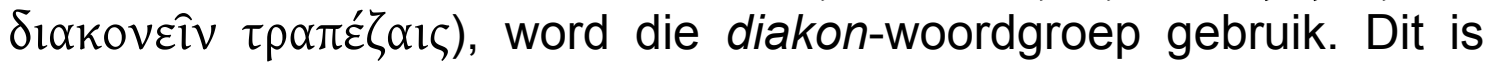
daarom belangrik dat die betekenis van hierdie woordgroep vasgestel word.

Oor die jare het algemene konsensus ontwikkel dat die diakonwoordgroep die primêre betekenis van fisieke versorging dra (vgl. Collins, 1990:5-45; Venter, 1996:43). Die fisieke versorging is volgens hierdie siening nóú met die tafelbediening van 'n kelner en 'n slaaf verbind. Die tafelbediening word gesien as diensbaarheid in nederige toewyding en is sterk verbind met slawediens (vgl. Beyer, 1964:81, 92; Louw \& Nida, 1989:484; Aitchison, 2003:84; Njiru, 2002:102, 103). Daar was egter ook voortdurend stemme wat vir 'n wyer verstaan van hierdie woordgroep gepleit het (vgl. Bruce, 1977:131; Venter, 1996:51).

By nadere ondersoek blyk dit dat eersgenoemde siening nie die volle omvang van die betekenisvelde waarin die woordgroep gebruik word, beskryf nie. Webber (2001:2) wys daarop dat wanneer die verspreiding of uitdeel van kos of geld in Handelinge ter sprake is, die begrippe $\delta 1 \alpha \mu \varepsilon \rho i ́ \zeta \omega$ en $\delta 1 \alpha \delta i \delta \omega \mu l$ gebruik word en nie $\delta 1 \alpha \kappa o v \varepsilon ́ \omega$ nie (vgl. Hand. 2:45 en 4:35). Lukas gebruik ook nie in die Lukasevangelie $\delta$ iakovía om verdeling of uitdeel te beskryf nie. Hy gebruik wel $\delta 1 \alpha \mu \varepsilon p i ́ \zeta \omega$ om die verdeling van Jesus se klere te

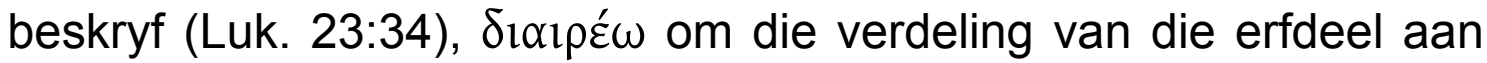
die verlore seun te beskryf (Luk. 15:12) en $\delta 1 \alpha \delta i \delta \omega \mu$ in die opdrag aan die ryk jongman om al sy goed onder die armes te verdeel (Luk. 18:22). Ook in Handelinge $2: 3$ word die begrip $\delta 1 \alpha \mu \varepsilon \rho i \zeta \omega$ vir die verdeling van die tonge van vuur op Pinksterdag gebruik. Hierdie

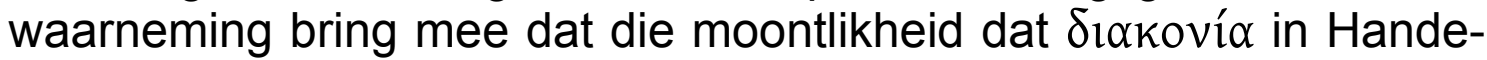
linge 6:1 bloot die uitdeel van voedsel beskryf, onwaarskynlik is (vgl. ook Finger, 2007:262).

Collins (1990) het 'n intensiewe studie gedoen aangaande die betekenisvelde van die diakon-woordgroep. Hy doen eksegese van elke Skrifdeel in die Nuwe Testament waar hierdie woordgroep voorkom. 
Hy ondersoek ook buite-bybelse bronne van die Nuwe-Testamentiese tyd en vergelyk die resultate van die twee studies met mekaar. Sy bevinding (Collins, 1990:252) is dat daar nie 'n verskil is in die betekenisvelde waarin die diakon-woordgroep in die Bybel en in buite-bybelse bronne gebruik word nie.

Sy gevolgtrekking is dat die diakon-woordgroep nêrens 'n aksie beskryf wat uit medemenslikheid of liefdesdiens gedoen word nie. Wanneer in ander se nood voorsien word, beskryf die diakon-woordgroep die uitvoering van 'n opdrag. Die woordgroep beskryf primêr 'n persoon of die werk van 'n persoon wat namens die een wat hom aangestel en gestuur het, optree. Liefdesdiens of tafelbediening is wel een van die moontlike betekenisvelde, maar dan is die persoon wat die bediening doen, iemand wat aangestel is om die taak te volvoer (Collins, 1990:251; 1995:167; 2002a:87). Verskeie skrywers beklemtoon in navolging van Collins dat die siening dat hierdie woordgroep primêr nederige dienswerk beskryf, oortuigend verkeerd bewys is (Craighill, 2006; Gooder, 2006; Barnett, 1995:21; Collins 2002b).

Bash (1997:29) lig 'n belangrike saak uit, naamlik dat die diakonwoordgroep in die Nuwe Testament gebruik word om 'n aktiwiteit te beskryf en dat dit nie die status van 'n persoon beskryf nie. Hy sê

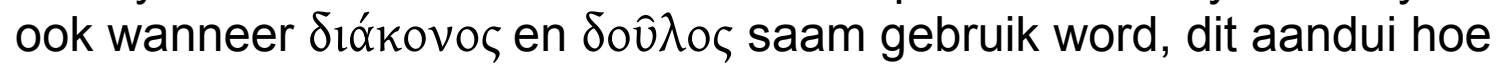
(met watter gesindheid) die aktiwiteit moet plaasvind, naamlik ' $n$ gevolmagtigde wat sy werk in nederige gehoorsaamheid aan sy opdraggewer doen.

Gooder (2006:48) toon aan dat die diakon-woordgroep wel verband hou met nederige diensbaarheid, veral wanneer dit saam met $\delta$ ov̂ $\lambda$ os gebruik word. Daarmee saam is dit duidelik dat die diakonwoordgroep oorvleulende betekenisvelde het met die teenoorgestel-

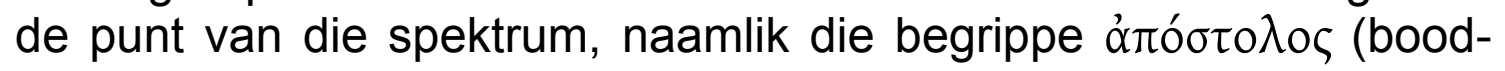
skapper) en $\pi \rho \varepsilon \sigma \beta u ́ \tau \varepsilon \rho \circ$ (om 'n ambassadeur te wees). Du Plooy (2005:562) sê tereg dat die diakon-woordgroep en roeping nóú met mekaar verbind is.

Hayler (2006:1) toon die volgende aan:

Diakonia is signifying the church's authoritative sending - the sense that ministry is something commissioned by the church, the people of God. Ministry is not a private or an ethical response, but a group of functions or activities that are constitutive for the church. Diakonia is an ecclesial category. 
The correction of the semantic field of the diakon words[:] There is a growing consensus that recognises that elements of menial, personal or loving service are not signified by these words.

Die invloedryke woordeboek A Greek-English Lexicon of the New Testament and other early Christian literature het ook sy verklaring van die diakon-woordgroep verander om bostaande insigte te verdiskonteer (vgl. Arndt et al., 1996; 2000).

Wanneer die bediening waarin die weduwees oor die hoof gesien is

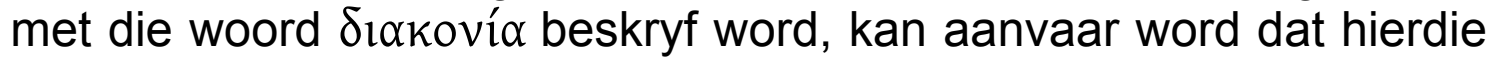
bediening deel was van die besondere bediening van die gemeente.

Dit blyk uit die voorafgaande:

- Die daaglikse bediening waarin die weduwees oor die hoof gesien is, kan nie op grond van die betekenis van die diakon-woordgroep beperk word tot die uitdeel van middele aan die armes nie.

- Die bediening van die tafels dui nie noodwendig op die voorsiening van kos of geld nie.

- Die bediening van die tafels was deel van die besondere (amptelike) bediening van die gemeente.

- Die bediening waarin die weduwees oor die hoof gesien is, was deel van die besondere bediening van die gemeente.

\subsubsection{Die weduwees en die daaglikse $\delta$ 1akovía}

Uit Handelinge 2 is dit duidelik dat die volgende daagliks in die gemeente plaasgevind het:

- Hulle het daagliks in die tempel bymekaargekom (Hand. 2:46) en het daar onderrig ontvang (Hand. 5:42) in die openbare erediens (gebede - Hand. 2:42; vgl. Bruce, 1977:81).

- Hulle het daagliks in kleiner groepe in huise bymekaar gekom waar hulle Nagmaal gevier (Hand. 2:46 - brood gebreek) en saam geëet (Hand. 2:46 - en hulle voedsel met eenvoud van hart geniet) het. 
- Hulle is ook daagliks in hierdie kleiner groepe onderrig deur die apostels (Hand. 5:42). 4

Al hierdie aspekte van die gemeentelewe word in Handelinge 6 met die diakon-woordgroep beskryf (vgl. Hovius, 1951:25).

Die praktiese situasie van die gebeure wat in Handelinge 6 beskryf word, kan soos volg voorgestel word. Elke dag het daar 'n groot menigte (Hand. 6:5) mense by die tempel bymekaar gekom, gelowiges, belangstellendes en nuuskieriges. Hier is hulle deur die apostels onderrig en het God in 'n erediens (gebede) aanbid. Hierdie deel van die bediening word in Handelinge 6 beskryf as $\tau \hat{\eta}$

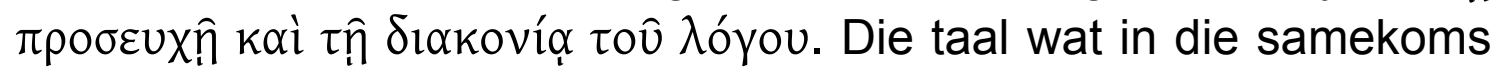
gebruik is, was waarskynlik Hebreeus (Bruce,1990:181), wat moontlik vir die Griekssprekendes 'n probleem kon skep (Talbert, 2005:59, 60; Finger, 2007:273). Dit is ook moontlik dat daar sinagoges was waar Grieks die voertaal was (Bruce,1990:181).

Van die tempel af is die gelowiges dan in groepe na verskeie huise om daar saam te eet, Nagmaal te vier en verder onderrig te word in die leer van die apostels (Hand. 2:42). Hierdie deel van die be-

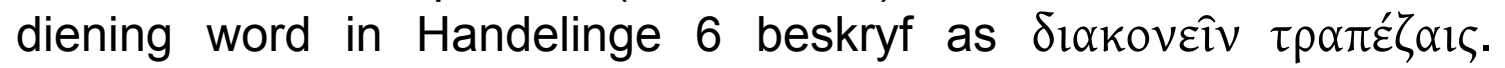

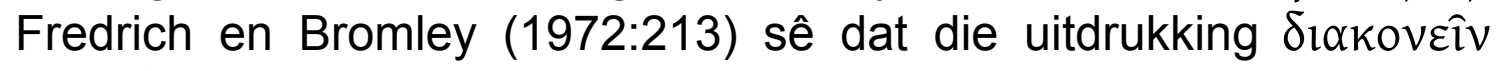

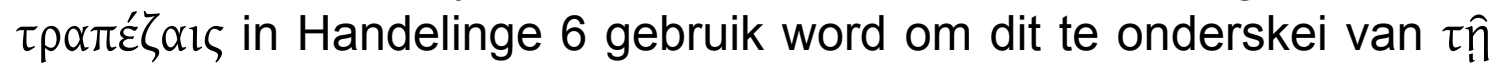

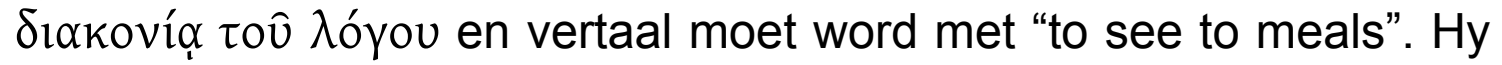
sien die bediening egter steeds te eng. Die bediening van die tafels het waarskynlik alle aspekte van die bediening by die huise ingesluit (Versteeg, 1982:20; Witherington, 2007:31).

Versteeg (1980:50-58) toon uit Handelinge, 1 Korintiërs 11 en ook 1 Korintiërs 10 aan dat die liefdesmaal, waar vir die armes gesorg is, en die Nagmaal aanvanklik altyd saamgegaan het. Die woord

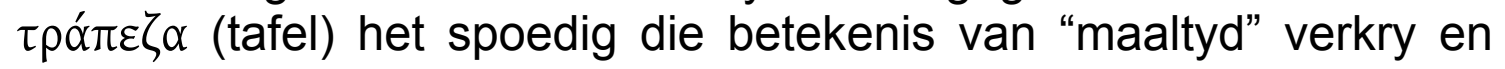
word in Handelinge 16:33 met hierdie betekenis gebruik (Fredrich, 1972:209, 213). Die Griekssprekende weduwees moes dus by 'n bepaalde huis inskakel, waar hulle dan onderrig en versorg moes word (Witherington, 1998:161). Dit is moontlik dat die apostels om die beurt by die verskillende huise die onderrig gaan doen en seker gemaak het dat die versorging plaasvind. Die verantwoordelikheid

$4 \quad$ Dit is onwaarskynlik dat die apostels elke dag by elke huis teenwoordig kon wees weens die aantal huise. Daar kon tussen 500 en 1000 huisbyeenkomste gewees het om meer as 5000 (Hand. 4:4 - 5000 mans) mense te akkommodeer. 
vir die onderrig en die versorging het egter normaalweg by die groep self gelê. Venter (1996:52) lei in navolging van verskeie skrywers uit Handelinge 2:45 in vergelyking met Romeine 12 af dat die gemeente self verantwoordelik was vir die uitdeel van die middele. Die apostels kon weens die groot getalle nie meer genoegsaam toesig en beheer uitoefen dat dit wel in alle huisgroepe plaasgevind het nie, wat die aanleidende oorsaak was van die weduwees se probleem (Hand. 6:1).

Dit blyk uit die voorafgaande dat:

- Die daaglikse bediening die bediening by die tempel asook die bediening by die huise ingesluit het.

- Die bediening by die tempel die bediening van die Woord en die gebede ingesluit het.

- Die bediening by die huise die onderrig in die Woord, die gemeenskaplike maaltyd, die versorging van armes en die Nagmaal ingesluit het.

\subsubsection{Die wyse waarop die weduwees afgeskeep is}

Die woord $\pi \alpha \rho \varepsilon \theta \varepsilon \omega \rho o \hat{v} \tau \tau$ (Hand. 6:1) word in die 1933/1953Afrikaanse vertaling met "oor die hoof gesien", vertaal en in die 1983-Afrikaanse vertaling met "afgeskeep". Die King James Version en die American Standard Version vertaal dit met "neglected". Louw en Nida (1989:356) noem nog een betekenismoontlikheid hierby en dit is "disregard". Die woord $\pi \alpha \rho \alpha \theta \varepsilon \omega \rho \varepsilon ́ \omega$ het geen regstreekse verband met afskeep ten opsigte van die armes se versorging nie. Die weduwees se behoeftes het dus op die een of ander manier in die totale bediening nie voldoende aandag gekry nie. Die weduwees is nie met respek behandel nie. Vermaak (2001:577) toon aan watter groot rol identiteit by maaltye gespeel het. Onbewustelik of bewustelik kon dit 'n rol gespeel het dat die Hebreeussprekendes die Griekssprekendes stief behandel het. Wat die versuim ook al was, dit het daartoe aanleiding gegee dat die weduwees dit as 'n groot probleem ervaar het en die Griekssprekendes daaroor gaan kla het.

Dit blyk uit die voorafgaande:

- Geeneen van die woorde waarmee die weduwees se probleem beskryf word, regverdig die gevolgtrekking dat die weduwees se probleem noodwendig by die gebrek aan voorsiening van voedsel of geld gelê het nie. 
- Daar kan nie met sekerheid gesê word waar die versuim in die daaglikse bediening van die weduwees plaasgevind het nie. Daar is verskeie moontlikhede:

- 'n Taalprobleem by die verkondiging in die tempel of by die huise;

- die weduwees is nie in 'n huisgroep ondervang nie en het gemeen hulle word uitgestoot;

- die huisgroep(e) waarby hulle betrokke was, het nie goed gefunksioneer nie en hulle is oorgeslaan by die uitdeel van kos en/of geld tydens die huisbyeenkoms;

- hulle was in 'n huisgroep wat nie middels ontvang het om uit te deel nie;

- daar is doelbewus of onbewustelik teen hulle gediskriminer deur die Hebreeussprekende Jode wat in die meerderheid was.

- Die weduwees het weens die versuim afgeskeep en beledig gevoel.

- Die klem word in hierdie deel daarop geplaas dat daar 'n probleem was wat tot skeuring in die gemeente kon lei. Wat die presiese aanleidende oorsaak tot die ongelukkigheid was, is duidelik 'n bysaak.

\subsection{Die wese en inhoud van die apostels en die sewe se bediening}

\subsubsection{Die wese en inhoud van die apostels se bediening}

Dit is belangrik om nader te probeer bepaal wat die dienswerk was

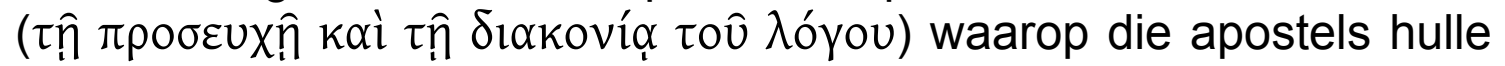
sou toespits. Uit Handelinge 1:25, by die verkiesing van 'n apostel in die plek van Judas, is dit duidelik dat die apostels se primêre taak was om as oor- en ooggetuies op te tree. Die nuwe apostel word verkies om deel te hê aan hierdie dienswerk en apostelskap ( $\lambda \alpha \beta \varepsilon \hat{\imath} v$

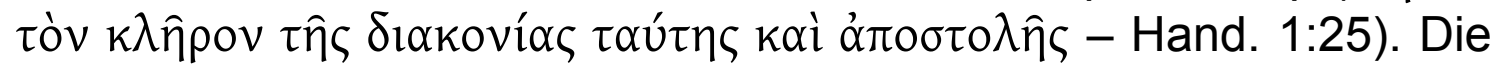
vereiste vir die een wat die dienswerk moet doen, word beskryf in vers 21,22 :

Daar moet dus nog 'n getuie van Jesus se opstanding by ons gevoeg word. Dit moet een van die manne wees wat saam met 
ons rondgegaan het die hele tyd toe die Here Jesus in die openbaar opgetree het, vandat Hy deur Johannes gedoop is totdat Hy van ons af in die hemel opgeneem is.

Wanneer die apostels dus besluit dat dit nie reg is dat hulle aandag afgetrek word van die bediening van die Woord nie, verwys die "bediening van die Woord" spesifiek na die oor- en ooggetuienis waarin hulle as gevolmagtigde verteenwoordigers van Jesus Christus onder leiding van die Heilige Gees optree (vgl. Kittel, 1967:115; Firet, 1974:40). Hulle was die enigstes wat die Woord as oor- en ooggetuies kon bedien. Dit is verstaanbaar dat hulle getuienis kosbaar was, omdat Jesus hulle juis daarvoor geroep en toegerus het. Indien hulle besig sou raak met ander dinge, selfs die onderrig van huis tot huis, kon dit hulle wegtrek van hierdie primêre bediening wat aan hulle, en hulle alleen, toevertrou is.

Saam met die Woordbediening sou hulle ook volhard in $\tau \hat{n}$ $\pi \rho \circ \sigma \varepsilon \cup \chi \hat{n}$. Die woord $\pi \rho \circ \sigma \varepsilon \cup \chi \hat{n}$ beteken onder meer gebed, maar kan ook 'n plek waar aanbidding plaasvind, of die erediens aandui (Greeven, 1968:808; Louw \& Nida, 1989:409). 'n Deel van die taak wat die apostels self sou behartig, was daarom waarskynlik die byeenkomste in die tempel (Bruce, 1990:183).

Hierdie perspektief versterk die siening dat die sewe ook die Woord verkondig het, maar in die kleiner groepies wat in huise vergader het. Hulle verkondiging was moontlik spesifiek in Grieks (Collins, 1990:216), en hulle verkondiging was waarskynlik die uitleg van die oor- en ooggetuienis van die apostels.

Venter (1996:50-52) verwoord 'n baie algemene wyse waarop met hierdie deel omgegaan word. Hy verbind Handelinge 2:42 met Handelinge 6:4 en vind 'n ringskomposisie in Handelinge 2:42:

Die gemeente het volhard in

A - die leer van die apostels

$\mathrm{B}$ - en (kai) in die onderlinge gemeenskap

$\mathrm{B}$ - en (kai) in die breking van die brood

A - en (kai) in die gebede.

Hy vind die A-A-been terug in Handelinge 6:4:

Maar ons sal volhard in: 
A - die bediening van die Woord

A - en die gebede.

Die apostels baken hulle werkveld af tot die A-A-been. Venter (1996:51) kom tot die gevolgtrekking dat die B-B-been van die ringskomposisie oorbly en dat die sewe mans wat verkies word, se taak deur die B-B-been van Handelinge 2:42 beskryf word.

In die A-A-been van Handelinge 2:42 is dit egter die hele gemeente wat volhard - nie in die bediening van die Woord (soos in Hand. 6:4) nie, maar in die leer van die apostels. Die bediening van die Woord en die volharding in die leer van die apostels is nie "letterlik dieselfde" soos Venter (1996:51) beweer nie. Die bediening van die Woord stel die gemeente wel in staat om die leer van die apostels te ken en daarin te kan volhard, maar daar is ' $n$ wesenlike verskil tussen hierdie twee aksies. Die apostels preek (as oor- en ooggetuies) en die gemeente neem hierdie getuienis en oordink dit en pas dit op hulle lewens toe. So volhard hulle daarin. Dit is dus nie geldig om 'n aftreksom te doen en tot die gevolgtrekking te kom dat Handelinge 6:4 beteken dat die sewe mans nie ook op die een of ander manier die Woord bedien het nie. Hulle Woordbediening verskil wel ingrypend van dié van die apostels, naamlik dat hulle in hulle verkondiging, dít wat hulle by die apostels gehoor het, toegepas het (vgl. Coetzee, 1967:48, 49).

In sy beredenering stel Venter (1996:51) die verkondiging van die apostels implisiet gelyk aan die verkondiging van ouderlinge en predikante, en die onderlinge gemeenskap en breking van die brood aan die diens van die diaken. Ook hierin is die redenasie egter nie konsekwent nie. Ouderlinge en predikante kan immers nooit as ooren ooggetuies van Jesus se leer en lewe optree nie. Dit wat die apostels as hulle werkveld toeëien, kan nie gelykgestel word aan die werkveld van ouderling en predikant nie.

Venter (1996:51) beperk verder die "breking van die brood" tot liefdesmaaltye. Dit is nie houdbaar nie. Van 't Spijker et al. (1980:10) toon duidelik aan dat die liefdesmaaltyd en die Nagmaal aanvanklik nie van mekaar geskei kon word nie en dat in Handelinge 2:42 met die breking van die brood, primêr die viering van die Nagmaal bedoel word (vgl. ook Coetzee, 1967:49; Witherington, 2007:30). Dat die Nagmaal en die liefdesmaaltyd in daardie tyd onlosmaaklik van mekaar gesien is, word ook duidelik wanneer Paulus in 1 Korintiërs 11 sê dat die gemeente se Nagmaalviering nie meer die Nagmaal van die Here is nie, omdat hulle liefdeloos optree tydens 
die liefdesmaaltyd. Indien die B-been in Handelinge 2:42 dus die diakens se werk beskryf, sou Nagmaalbediening ook deel moes uitmaak van die diakens se taak (Grosheide, 1957:304, 305).

Indien "die breking van die brood" gelykgestel word aan slegs die liefdesmaaltyd, en koinonia die onderlinge gemeenskap is, het die onderskeid wat deur die kai-verbinding (Handelinge 2:42) daargestel word, nie sin nie. Die liefdesmaaltyd, wat versorging van die armes ingesluit het, was so 'n integrale deel van die koinonia dat Lukas die liefdesmaaltyd en die onderlinge gemeenskap slegs met die woord koinonia sou kon beskryf en almal sou begryp dat die liefdesmaaltyd daarby ingesluit was. Hy tref egter 'n doelbewuste onderskeid deur die kai-verbinding en deur die ringskomposisie. Indien die A-Averbinding twee afsonderlike en tog nóú verwante sake benoem, kan tereg verwag word dat die B-B-been ook twee afsonderlike, hoewel nóú verwante sake sal benoem.

Wanneer die apostels sê dat dit nie reg sal wees as hulle by die bediening van die tafels betrokke raak en daardeur die bediening van Woord en gebede afskeep nie, beperk hulle hulle eie arbeidsterrein en nie dié van die sewe mans nie. Indien die apostels steeds van huis tot huis die Woord moes gaan verkondig, sou hulle las nie veel verlig geword het deur die nuwe voorgangers nie. Dit sou egter groot verligting bring indien die apostels die huis-tot-huis-bediening, wat duidelik onderskeibaar is van die bediening by die tempel, aan ander voorgangers sou kon oorgee.

Dit blyk uit die voorafgaande dat:

- die apostels ná die verdeling van die werk gefokus het op die oordra van die oor- en ooggetuienis binne die gesamentlike eredienste wat in die tempel gehou is;

- dit die sewe se taak was om die res van die bediening te behartig sodat die apostels ongehinderd met hulle hooftaak kon voortgaan.

\subsubsection{Die wese en inhoud van die sewe se opdrag}

\subsubsection{Regeer (bestuur en beheer)}

Handelinge 6:1-7 word omsluit deur twee mededelings dat die gemeente gegroei het (Hand. 6:1 en 6:7). Ook die groter konteks dui daarop dat Lukas die groei van die kerk deur die verkondiging van die evangelie beskryf (vgl. 2.2). Uit sowel die breër konteks as uit Handelinge 6 is dit duidelik dat daar 'n doelbewuste aanslag was om 
hierdie groei te stuit en dat Lukas aandui hoe die kerk ondanks en selfs as gevolg van hierdie aanslae groei. Handelinge 6:1-7 is 'n beskrywing van die tweede aanslag wat van binne die kerk self kom (vgl. 2.2). Daar is reeds aangedui (vgl. 2.2) dat Lukas in Handelinge 6:1-7 beskryf hoe die kerk, sonder dat God 'n wonderwerk gee, in die wysheid van die Gees die aanslag moet afweer en dit as geleentheid vir groei moet benut.

Die opdrag van die sewe moet teen hierdie agtergrond begryp word. Hulle opdrag was om die bedreiging wat die ontevredenheid van die weduwees meegebring het, op te los. Hiervoor sou hulle die bestuur- en beheerprobleem wat deur die groeiende getalle geskep is, moes takel (Barclay, 2003:59). Handelinge 6:1-7 is dus nie primêr 'n beskrywing van hoe die kerk haar weduwees of armes of mense wat deur die een of ander oorsaak buite die liefdesgemeenskap gestoot word, moet versorg nie. Dit handel nie in die eerste plek oor die seerkry van 'n groep lidmate nie. Dit gaan eerder oor die bedreiging wat hierdie ongelukkigheid vir die hele gemeente en die uitdra van die Woord inhou as dit nie aandag kry nie. Daarom word die hele menigte dissipels (Hand. 6:2) betrek by die soeke na 'n oplossing (Finger, 2007:265).

'n Tweede bedreiging word deur die apostels uitgelig wanneer hulle sê dat dit nie reg sal wees dat hulle die bediening van die Woord afskeep om die tafels te bedien nie. Dit het ook te doen met bestuur en beheer binne die gemeente. Dit het te doen met prioriteite en die bepaling van fokusgebiede vir bepaalde gawes en met die delegering van verpligtings.

Lukas beklemtoon aan die een kant die wonderlike groei wat daar in die kerk plaasgevind het, maar hy maak dit ook duidelik dat daar uit verskeie oorde, van binne en buite, probleme kan opduik. In Handelinge 6:1-7 beskryf hy die bestuur en beheer van probleme wat opgeduik het toe die gemeente in Jerusalem vinnig gegroei en die werk vir die bestaande voorgangers te veel geraak het. Die gevolg

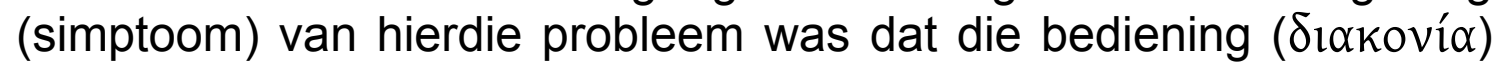
skade gely het. In hierdie besondere geval was dit die versuim ten opsigte van die weduwees wat eerste kop uitgesteek het. Die apostels sou hierdie simptoom kon probeer beredder deur nog meer by die bediening by die huise en die bediening van individue en groepe betrokke te raak. Dit sou egter skynbaar slegs die probleem tydelik opgelos het, omdat die werklike probleem dan nie getakel sou word nie. 'n Ander simptoom van die werklike probleem sou dan 
gou opgeduik het - dat die apostels nie die Woord sou kon bedien soos hulle moes nie en die eredienste ook skade sou ly.

Die apostels identifiseer die werklike probleem, naamlik dat die twaalf apostels te min is om toe te sien dat die bediening ( $\delta_{1 \alpha \kappa o v i ́ \alpha)}$ doeltreffend plaasvind. Hulle word deur die Heilige Gees gelei om te besef dat hulle bekwame lidmate (mense vol van die Heilige Gees) moet kry om hulle te help - dit is moontlik gegrond op die raad wat Jetro aan Moses gegee het (vgl. Eks. 18; Bruce, 1990:182). Hulle takel die werklike probleem deur nog voorgangers te laat kies wat hulle kan bystaan sodat die bediening ( $\delta$ i $\alpha$ koví $\alpha$ ) doeltreffend kan plaasvind. Die volgende stap in die oplossing van die probleem was werksverdeling. Die apostels kies die werksterrein waarvoor hulle deur Jesus geroep en toegerus is en wat niemand anders kan doen nie, naamlik die bediening van die Woord as oor- en ooggetuies. Daarmee saam het hulle die aanbidding soos dit in die erediens plaasvind, gelei.

Die sewe ontvang die taak om die res van die bediening te behartig, wat hoofsaaklik tydens die byeenkomste van huis tot huis plaasgevind het.

Dit wat in Efesiërs $4^{5}$ van die besondere gawes (bv. herders en leraars) gesê word, dat hulle soos ligamente is wat die liggaam glad moet laat funksioneer (Roberts, 1963:146; Breed et al., 2008:21), word hier prakties geillustreer. Die haakplekke wat ontstaan het in die bediening ( $\delta 1 \alpha$ koví $\alpha$ ) moes deur die nuwe voorgangers uitgestryk word (vgl. Du Plooy, 2005:564).

\subsubsection{2 'n Pastorale dimensie}

Om die volle inhoud van die sewe se opdrag te begryp, is dit nodig om Handelinge 6:1 in meer diepte te ondersoek. In Handelinge 6:3 sê die apostels dat sewe mans gekies moet word om oor "hierdie saak" aangestel te word. Daar is reeds vasgestel dat 'n deel van "hierdie saak" die bestuur en beheer is oor die bediening in die byeenkomste wat van huis tot huis plaasgevind het - die doel was om tekortkomings in die bediening te takel (vgl. 3.3.2.1). Daar is ook vasgestel (vgl. 3.2.3) dat die weduwees moontlik die optrede teenoor hulle as beledigend ervaar het. Hulle murmurering het dus waarskynlik nie bloot oor die versuim gegaan nie, maar ook oor die

$5 \quad$ Vergelyk Kruger (2005:527-553) vir die roeping en taak van die besondere dienste in die kerk. 
moontlike gesindheid (minagting) wat tot die versuim aanleiding gegee het.

Dit is duidelik dat Lukas die murmurering van die weduwees beklemtoon deur taamlik uitgebreid daaroor te skryf. Die volgende uiteensetting dui aan watter aspekte van hulle murmurering hy uitlig:

$\rightarrow$ Wanneer die murmurering onstaan

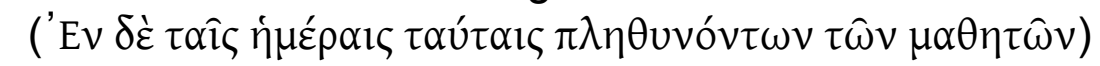

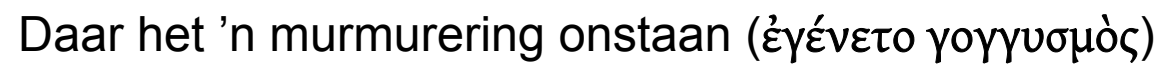

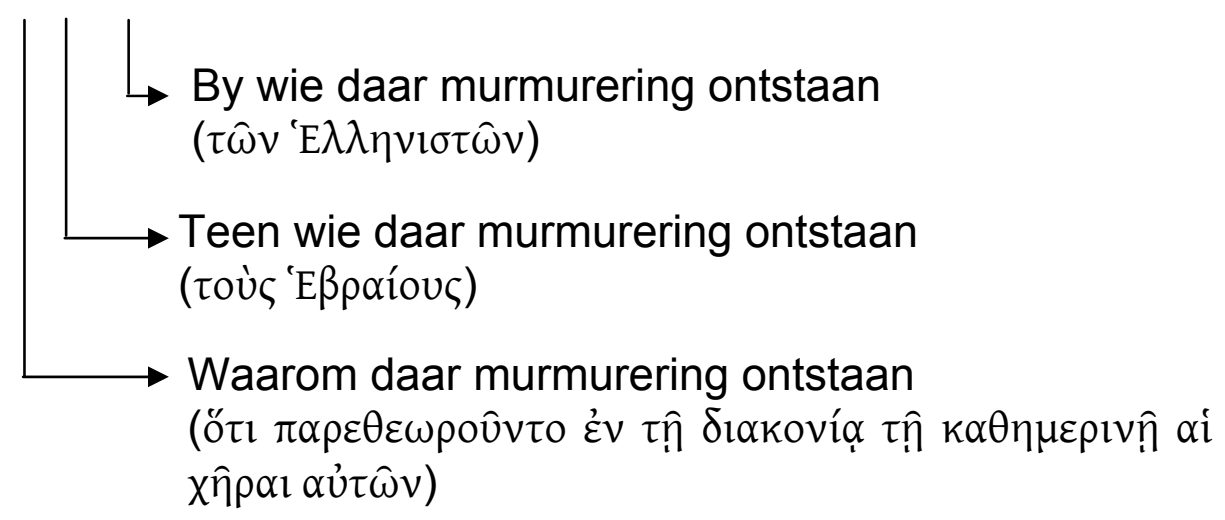

Murmurering dui op ongelukkigheid en selfs agterdog (White, 2005: 88). Die erns van die situasie het in die moontlikheid van skeuring gelê. Indien daar net aandag gegee sou word aan die oorsig, kon daar nog twyfel bestaan het oor die Hebreeussprekendes se gesindheid teenoor die Griekssprekendes. Dit is duidelik dat die moontlikheid van agterdog oor gesindheid en die moontlike spanning tussen die twee groepe ondersoek en getakel moes word voordat daar selfs aan nuwe strukture vir die bediening gedink kon word. Daar kan dus aangeneem word dat die opdrag van die sewe ook 'n pastorale dimensie gehad het, met die oog op eenheid in die gemeente.

Daar kan afgelei word dat dit wat in Efesiërs 4 as doel van die besondere dienste gestel word, naamlik om die eenheid in die gemeente te laat groei (Kruger, 2005:535), duidelik ook deel van die opdrag van die nuwe voorgangers was.

\subsubsection{Verkondiging van die Woord}

Dit het reeds duidelik geword dat die uitleg en onderrig van die apostels se oor- en ooggetuienis waarskynlik deel was van die sewe se taak by huisbyeenkomste (vgl. 3.3.1). Witherington (1998:251) bied 'n verdere bevestiging van hierdie waarneming. Hy wys op 
Lukas se literêre styl waarvolgens 'n persoon wat in die volgende deel van sy beskrywing van die geskiedenis 'n belangrike rol gaan speel, reeds in die vorige deel bekendgestel word. Hy noem hierdie persone brugfigure. 6 Volgens hom is Stefanus en Filippus twee brugfigure wat in Handelinge 6:1-7 bekendgestel word en dan in die daaropvolgende dele 'n belangrike rol speel (vgl. ook Talbert, 2005: $60)$. In die daaropvolgende dele word beskryf hoe hierdie twee persone die Woord verkondig en doop. Filippus word ook as evangelis aan die leser voorgestel. Daar kan dus met reg aangeneem word dat dit wat hulle in die tyd ná die gebeure van Handelinge 6 doen, ook deel van die opdrag was wat hulle in Handelinge 6 ontvang het.

Die toerusting van die gemeente wat volgens Efesiërs 4 die doel van die besondere dienste is (vgl. Kruger, 2005:536), was duidelik ook deel van hierdie sewe voorgangers se opdrag.

\subsubsection{Bediening van die Nagmaal}

Daar is reeds aangetoon dat die breking van die brood ook die Nagmaal, wat ten nouste met die liefdesmaaltye saamgehang het, ingesluit het (vgl. 3.3.1). Die sewe moes dus ook die Nagmaal van huis tot huis bedien.

\subsubsection{Gevolgtrekking}

- Die sewe word geroep en bevestig as voorgangers van die gemeente.

- Hul taak het ingesluit:

- 'n pastorale funksie;

- die regering - die bestuur en beheer van die bediening

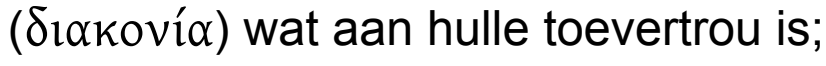

- die versorging van armes en die bevordering van die koinonia;

- die onderrig oor en toepassing van die getuienis van die apostels; en

- die bediening van die Nagmaal.

6 So word Barnabas in Handelinge 4:36 aan die lesers voorgestel om vanaf Handelinge 9 'n groter rol te speel. Saulus (Paulus) word in Handelinge 7:58 bekendgestel voordat hy in die volgende hoofstukke 'n prominente rol vertolk. 
- Hulle taak toon ooreenkomste met die taak wat in Efesiërs 4 aan die besondere dienste opgedra word en wat sowel die take van die latere ouderlinge as die diakens ingesluit het.

\subsubsection{Die sewe in 'n besondere diens}

Coetzee (1967:44) en Venter (1996:50) lei op grond van vyf faktore af dat Handelinge 6 die instelling van 'n nuwe besondere diens beskryf. Hierdie faktore is:

- Die gemeente word saamgeroep

- Die sewe word deur die gemeente gekies

- Hulle word voor die apostels gestel

- Hulle word die hande opgelê terwyl vir hulle gebid word

- Hulle ontvang 'n spesifieke opdrag

Hulle vind bevestiging vir hierdie afleiding deur Handelinge 6 met Handelinge 1 en 14 te vergelyk. Handelinge 1 en 14 beskryf egter die verkiesing van mense tot 'n bestaande besondere diens en nie die instelling van 'n besondere diens nie. In albei gevalle word die besondere diens waartoe die persone verkies word ook duidelik genoem. Die noem van 'n permanente besondere diens is opvallend afwesig in Handelinge 6.

Die feit dat die sewe die hande opgelê is, speel 'n belangrike rol om Coetzee (1967:44) en Venter (1996:50) te oortuig dat die sewe in 'n permanente besondere diens bevestig is. Indien die betekenis en praktyk van handoplegging bestudeer word, dui handoplegging egter nie noodwendig op die bevestiging in 'n besondere diens nie. Handoplegging is 'n simboliese daad waarmee die gemeente deelname en betrokkenheid by die taak wat verrig moet word, getuig. Phillips (2001:154) sê dat handoplegging altyd identifisering met iets of iemand simboliseer, soos in 1 Timoteus 5:22 waar Timoteus gewaarsku word om nie iemand te vinnig die hande op te lê en miskien deel te word van iemand anders se sonde nie.

Dit is belangrik om in gedagte te hou dat die handoplegging gebruik is as simboliese daad om iemand af te sonder, nie net vir 'n besondere diens nie, maar ook vir 'n besondere (eenmalige/tydelike) opdrag (Ryken et al., 1998:362; O'Collins \& Kendall, 1997:144-146; Witherington, 1998:251; Talbert, 2005:60). Handelinge 13 beskryf so 'n geval. In Handelinge 13:1 word Barnabas en Saulus saam met ander genoem as profete en leraars in die gemeente van Antiogië. 
Terwyl hulle een maal bymekaar was om die Here te dien en gevas het, het die Heilige Gees hulle opdrag gegee om Saulus en Barnabas af te sonder vir 'n besondere taak (Hand. 13:2). Hulle moes die evangelie na die heidene uitdra. Die gemeente het toe gevas, hulle die hande opgelê en hulle gestuur om hierdie taak aan te pak. Sowel Barnabas as Saulus was dus reeds in 'n bepaalde permanente diens bevestig, maar word (weer) die hande opgelê sonder dat daar van ' $n$ besondere diens sprake is. Hierdie handoplegging is dus duidelik nie noodwendig die bevestiging in 'n bepaalde besondere diens nie, maar het te make met die bepaalde opdrag waarvoor die gemeente hulle stuur. Nee $(1996: 125,126)$ sê dat die handoplegging in Handelinge 13 die betekenis gedra het van: “... their going was the whole church's going". Die handoplegging het geïmpliseer dat dit nie slegs Saulus en Barnabas was wat na Antiogië gegaan het nie, maar dat die hele gemeente saam met hulle gegaan het.

Die oplê van hande simboliseer kommunikasie, oordrag en ontvangs, nie 'n statiese oordrag nie, maar 'n voortdurende interaksie met God (Stookey, 2000:147-148). Handoplegging het in verskeie situasies plaasgevind. Die oordrag kan wees genesing (Mark. 5:23; Hand. 9:12; 28:8), geestesgawes (Hand. 8:19; 19:6), bevestiging/afsondering (Hand. 6:6; 13:13; 1 Tim. 4:14; 5:22; 2 Tim. 1:6) of seën (Matt. 19:13-17; vgl. Bruce, 1990:184, 185). Die oplegging van die hande is ook deurlopend simbolies van die teenwoordigheid van die Heilige Gees (Hamilton, 2000:796).

Die sewe is deur die gemeente verkies, deur die apostels die hande opgelê en 'n bepaalde opdrag gegee. Dit is uit die voorafgaande duidelik dat daar nie op grond hiervan 'n keuse gemaak kan word tussen die moontlikheid dat hulle hierdie diens permanent beklee het en of dit 'n roeping was tot die eenmalige hantering van 'n bepaalde probleem nie. Veel minder nog kan hieruit afgelei word dat die kerke op grond van die beskrywing van hierdie gebeure die instelling van ' $n$ bepaalde besondere diens kan aflei of die taakomskrywing van 'n bepaalde besondere diens hieruit kan vasstel.

Wat wel duidelik is, is dat hulle as voorgangers deur die gemeente geroep en afgesonder is vir ' $n$ bepaalde taak. Hulle tree as gevolmagtigdes van die gemeente op in die uitvoering van hulle opdrag. Hulle roeping vertoon eienskappe van die besondere dienste wat Christus aan sy kerk skenk (Ef. 4). Dit blyk dat Handelinge 6 'n embriodiens beskryf waaruit die verskillende besondere dienste sou ontwikkel. Du Plooy (2005:563) toon aan dat daar selfs in die briewe van Paulus 'n ontwikkeling plaasvind in wat Paulus oor die besondere dienste leer. Soos Paulus, het Lukas ook nie van die 
Here 'n klaargemaakte bedieningstruktuur of ampsbeskouing ontvang nie. Die Gees het dit laat ontwikkel en gaandeweg die pad gewys. Van Handelinge 6 tot dit wat Paulus in Efesiërs en die briewe aan Timoteus leer, moes daar nog baie water in die see loop. Om dus uit Handelinge 6 'n uitgewerkte pligstaat vir die diaken af te lei, sou nie verantwoordbaar wees nie (vgl. Bruce, 1990:182). Nel (2009:7) praat van natuurlike kerkontwikkeling wat 'n dinamiese proses is waarin die Drie-enige God se antwoorde op die vrae wat Hy op die pad van 'n gemeente bring, gesoek word. Die antwoorde wat gevind word, kan gaandeweg tot ordelike strukture groei, soos dit wel duidelik word in die loop van Handelinge en die briewe van Paulus en Petrus.

Uit die voorgaande blyk die volgende:

- Daar kan nie in Handelinge 6:1-7 genoegsame getuienis gevind word om af te lei dat die instelling van die besondere diens van diaken in hierdie gedeelte beskryf word nie.

- Handoplegging dui nie altyd op die bevestiging in 'n besondere diens nie.

- Volgens Handeling 13 het die gemeentes ook mense verkies en afgesonder om 'n besondere taak te verrig, sonder dat hulle noodwendig in ' $n$ besondere diens (amp) bevestig is.

- Daar kan in die Skrif 'n ontwikkeling in die ampsbeskouing aangetoon word. Die oplossing vir 'n besondere probleem, die verkiesing van meer voorgangers, kan gesien word as die embrio waaruit meer permanente strukture kon ontwikkel.

\section{Gevolgtrekking}

Daar kan nie met sekerheid gestel word dat die instelling van die besondere diens van diaken in Handelinge 6 beskryf word nie en ook nie dat hierdie gedeelte oor die instelling van enige besondere diens handel nie. Lukas beskryf wel in Handelinge 6 'n praktiese ad hoc-ordereëling van 'n gemeente. Volgens die ordereëling wat getref is, is die bedieningswerk verdeel sodat die apostels kon fokus op dit waarvoor hulle primêr deur Jesus geroep en toegerus is, naamlik om oor- en ooggetuies te wees. Die nuwe voorgangers is geroep en afgesonder om daardie werk te behartig wat die probleem/behoefte in die gemeente sou takel. Hierdie ordereëling kon die embrio gewees het waaruit meer permanente strukture gegroei het. 


\section{Moontlikheid vir verdere navorsing}

- Indien die wese en inhoud van die besondere diens van diaken nie uit Handelinge 6:1-7 afgelei kan word nie, moet opnuut nagevors word hoe die besondere diens van diaken ontstaan het en wat die diaken se taak behoort te wees.

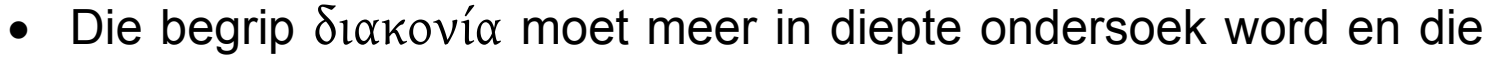
resultate van so 'n ondersoek moet op die bedieningstrukture van die gemeentes toegepas word. Hierdie ondersoek kan ook leiding verskaf oor die vraagstuk van die vrou se dienswerk in die kerk.

\section{Geraadpleegde bronne}

AITCHISON, R. 2003. The ministry of a deacon. Peterborough: Epworth.

ARNDT, W., DANKER, F.W. \& BAUER, W. 2000. A Greek-English Lexicon of the New Testament and Other Early Christian Literature: based on Walter Baur's Griechisches-Deutsches Wörterbuch zu den Schriften des Neuen Testaments und der übrigen urchristlichen Literatur. 3rd rev. ed. Chicago: University of Chicago Press.

ARNDT, W., DANKER, F.W., BAUER, W. \& GINGRICH, F.W. 1996. A GreekEnglish Lexicon of the New Testament and Other Early Christian Literature. Chicago: University of Chicago Press.

BARCLAY, W. 2003. The new daily study Bible: the Acts of the apostles. Kentucky: John Knox.

BARNETT, J.M. 1995. The diaconate: a full and equal order. Revised ed. Valley Forge: Trinity.

BASH, A. 1997. Ambassadors for Christ: an exploration of ambassadorial language in the New Testament. Tübingen: Mohr.

BEYER, H.W. 1964. "Diakonew, Diakonia, Diakonos". (In Bromley, G.W., ed. Theological Dictionary of the New Testament. Vol. 2. Grand Rapids: Eerdmans. p. 81-93.)

BREED, D.G., JORDAAN, G.J.C. \& VAN RENSBURG, F.J. 2008. Manlik en vroulik in die kerk: geslagtelikheid en die besondere dienste. Potchefstroom: Potchefstroomse Teologiese Publikasies.

BRUCE, F.F. 1977. The book of the Acts. Grand Rapids: Eerdmans.

BRUCE, F.F. 1990. The book of Acts: Greek text and commentary. 3rd rev. \& enl. ed. Grand Rapids: Eerdmans.

COETZEE, J.C. 1967. Enkele Skrifgegewens oor die diakenamp: Handelinge 6 en die diakenamp. In die Skriflig, 1(4):44-49.

COLLINS, J.N. 1990. Diakonia: re-interpreting the ancient sources. Oxford: Oxford University Press.

COLLINS, J.N. 1995. A ministry for tomorrow's church. Journal of ecumenical studies, 32(2):159-178.

COLLINS, J.N. 2002a. Deacons and the church: making connections between old and new. Herefordshire: Gracewing.

COLLINS, J.N. 2002b. Contextualising Dorothea Reininger's women deacons. http://www.womenpriests.org Date of access: 13 Oct. 2008.

CRAIGHILL, G, 2006. Review. http://ccat.sas.upenn.edu/bmcr/1991/ 02.05.06.html. Date of access: 8 Feb. 2010. 
DU PLOOY, A. LE R. 2005. Die betekenis van charisma en amp vir die kerkregering. In die Skriflig, 39(3):555-567.

FINGER, F.H. 2007. Of widows and meals: communal meals in the book of Acts. Grand Rapids: Eerdmans.

FIRET, J. 1974. Het agogisch moment in het pastoraal optreden. Kampen: Kok.

FRIEDRICH, G. \& BROMLEY, G.W. 1972. Theological Dictionary of the New Testament. Vol. 8. Michigan: Eerdmans.

GOODER, P. 2006. Diakonia in the New Testament: a dialogue with John N. Collins. Ecclesiology, 3(1):33-56.

GREEVEN, H. 1968. Proseugomai. (In Bromley, G.W., ed. Theological Dictionary of the New Testament. Vol. 2. Grand Rapids: Eerdmans. p. 807-808.)

GROSHEIDE, F.W. 1957. De eerste brief aan de kerk te Korinthe: commentaar op het Niewe Testament. Kampen: Kok.

HAMILTON, M.W. 2000. Laying on of hands. (In Eerdmans, W.B., ed. Dictionary of the Bible. Michigan: Eerdmans. p. 796.)

HAYLER, P. 2006. Response to Paula Gooder's paper on the scholarship of John N. Collins. Paper presented at the Communion of the Porvoo Churches Consultation on the Diaconate, 25-27 January 2006, the Royal Foundation of Saint Katharine London. http://www.porvoochurches.org/ last4years/london.html Date of access: 10 Feb. 2010.

HOVIUS, J. 1951. Behooren de diaken tot den kerkraad? Sneek: Weissenbach.

KITTEL, G. 1967. Lego, logos, rema, laleo. (In Bromley, G.W., ed. Theological Dictionary of the New Testament. Vol. 4. Grand Rapids: Eerdmans. p. 69143.)

KRUGER, S.F. 2005. Toerusting as wordingsproses: perspektiewe uit die Efesiërbrief. In die Skriflig, 39(3):527-553.

LOUW J.P. \& NIDA, E.A. 1989. Greek-English Lexicon of the New Testament: based on semantic domains. 2nd ed. New York: United Bible Societies.

NEE, W. 1996. The assembly. Anaheim: Life Living Stream Ministry.

NEL, M. 2009. Congregational analysis revisited: empirical approaches. Hervormde teologiese studies, 65(1):13.

NJIRU, P.K. 2002. Charisms and the Holy Spirit's activity in the body of Christ: an exegetical-theological study of 1 Corinthians 12:4-11 and Romans 12:6-8. Gregoriana: Editrice Pontificia Università.

O'COLLINS, G. \& KENDALL, D. 1997. The Bible for theology: ten principles for the theological use of Scripture. New York: Paulist.

ROBERTS, J.H. 1963. Die opbou van die kerk volgens die Efese-brief.

Kampen: Theologische Hogeschool. (Th.D.-proefskrif.)

PHILLIPS, J. 2001. Exploring Acts: an expository commentary. Grand Rapids: Kregel.

RYKEN, L., WILHOIT, J.C., LONGMAN, T., DURIEZ, C., PENNEY, D. \& REID, D.G. 1998. Dictionary of Biblical Imagery: an encyclopedia exploration of the images, symbols, motifs, metaphors, figures of speech, literary patterns and universal master images of the Bible. Illinois: InterVarsity.

STOOKEY, L.H. 2000. Baptism. (In Eerdmans W.B., ed. Dictionary of the Bible. Michigan: Eerdmans. p. 147-148.)

TALBERT, C.H. 2005. Reading Acts: a literary and theological commentary on the Acts of the apostles. Boston: Smyth \& Helwys. 
VAN 'T SPIJKER, W., BALKE, W., EXALTO, K. \& VAN DRIEL, L. 1980. Bij brood en beker: leer en gebruik van het heilig avondmaal in het Nieuwe Testament en in de geschiedenis van de westerse kerk. Goudriaan: De Groot.

VENTER, C.J.H. 1996. Uitkringende liefdesbetoon: kommunikatiewe handelinge in diens van die onderlinge liefdesgemeenskap in die kerk. Pretoria: Raad vir Geesteswetenskaplike Navorsing.

VERMAAK, S.P.J. 2001. Saam eet in Handelinge 2:42: 'n sosio-historiese ondersoek. In die Skriflig, 35(4):575-589.

VERSTEEG, J.P. 1980. Het avondmaal volgens het Nieuwe Testament. (In Van 't Spijker, W., Balke, W., Exalto, K. \& Van Driel, L., reds. Bij brood en beker: leer en gebruijk in het Nieuwe Testament en in die geschiedenis van de westerse kerk. Goudriaan: De Groot. p. 9-64.)

VERSTEEG, J.P. 1982. Nieuwtestamentish profiel van die ouderling. (In Koole, D. \& Velema, W.H. Uit liefde tot Christus en zijn gemeente: een handreiking aan de ouderling. Kampen: Kok. p. 11-55.)

WALLACE, D.P. 1998. Acts: introduction, outline, and argument. Biblical Studies Press.

WEBBER, D.J. 2001. Acts 6:1-6: an exegetical inquiry. http://www.angelfire. com/ny4/djw/ lutherantheology.actsvi1-6.html Date of access: 10 Feb. 2010.

WHITE, E.G. 2005. Acts of the apostles. Tellico Plains: Digital Inspiration.

WITHERINGTON, B. 1998. The Acts of the apostles: a socio-rhetorical commentary. Cambridge: Eerdmans.

WITHERINGTON, B. 2007. Making a meal of it: rethinking the theology of the Lord's Supper. Waco: Waco University Press.

\section{Kernbegrippe:}

diakens

diakonia

Handelinge 6

Key concepts:

Acts 6

deacons

diakonia 
